УДК 502.4(477.42)

DOI: https://doi.org/10.26642/ten-2021-2(88)-135-147

\section{К.О. Осадчук, студентка \\ І.В. Давидова, к.с.-г.н., доц. \\ М.Б. Корбут, к.т.н., доц. \\ В.М. Бондарчук, ст. викладач}

В.В. Бабяк, аспірант

Державний університет «Житомирська політехніка»

\title{
Репрезентативність природних екосистем у природно-заповідному фонді Житомирської області
}

\begin{abstract}
У роботі досліджено репрезентативність природних екосистем на території природних заповідників Житомирської області: природного заповідника «Древлянський» та Поліського природного заповідника. Вивчено сучасний стан і екологічне значення природних екосистем, зокрема наземних (лісових) та прісноводних (річок $і$ боліт). Розглянуто основні проблеми охорони та збереження представлених природних екосистем на територіі природних заповідників Житомирського Полісся. Встановлено зростання площ природно-заповідного фонду Житомирської області впродовж останнього десятиліття, а отже й збільшення екосистем. Проаналізовано динаміку структурних компонентів заповідного фонду області. Показник заповідності в регіоні становить 4,5\% і залишається стабільно низьким порівняно з іншими областями Украӥни, при загальному показнику по країні 6,6 \%. Виявлено прогресуючі антропогенні зміни щзодо зменшення водно-болотних угідь, фактичну відсутність оздоровчих заходів на територіях розміщення лісових екосистем. Під час зіставлення територій природних заповідників встановлено суттєві перевищення одних природних екосистем над іниими за співвідношенням часток площі. Тому необхідно забезпечити відновлення ключових елементів екосистем, щзо зазнали руйнацій, та організувати догляд за існуючими природніми екосистемами заповідників.
\end{abstract}

Ключові слова: екосистема; природні заповідники; природно-заповідний фонд; ліс; болото.

Вступ. Заповідання екосистем природного походження є важливим завданням сьогодення [1]. Насамперед створення заповідників дає можливість зберегти генофонд рослинного та тваринного світу, згодом і саму структуру екосистем. Екосистема природного походження стає прикладом для створення штучних екосистем. У цьому аспекті своєрідною структурою, флорою та фауною, ландшафтним різноманіттям характеризуються й екосистеми природного походження Житомирщини [2]. Аналіз сучасного стану природно-заповідного фонду (ПЗФ) Житомирської області, розгляд проблем і перспектив його розвитку - питання надзвичайно важливі для сьогодення. За останні двадцять років кількість природно-заповідних об'єктів області зросла, значно збільшилась і площа, зокрема за рахунок територій, які зазнали радіоактивного забруднених після аварії на Чорнобильській АЕС [3].

Проводячи аналіз функціонально-просторового стану мережі ПЗФ Полісся, виявлено, що він не $є$ оптимальним $[4,5]$. Це визначається малим і непропорційним ступенем заповідання території регіону, незначною кількістю природоохооронних об'єктів поліфункціонального значення. Мережа територій i об’єктів ПЗФ регіону в географічному просторі сформована нерівномірно як в широтному, так і меридіональному аспектах [5, 6]. Ступінь концентрації об’єктів ПЗФ зменшується із заходу на схід, і 3 півночі на південь. Більшість об'єктів ПЗФ Полісся входять до складу регіональної екологічної мережі (EM) як біоцентри, біогеоценози, частина ареалів сполучних територій. Проте майже не проводиться їх аналіз на відповідність як природним ядрам, так і територіям рекреаційного призначення [7]. Ключові території (природні ядра) екомережі, як правило, утворюють об’єкти ПЗФ [5, 6].

Відповідно до даних, наведених на офіційному сайті Міністерства екології та природних ресурсів України [8], складених за результатами даних обліку територій та об'єктів природно-заповідного фонду, поданих органами виконавчої влади на місцевому рівні, що забезпечують реалізацію державної політики у сфері охорони навколишнього природного середовища, станом на 01.01.2021 р. природно-заповідний фонд України має в своєму складі 8245 територій та об'єктів загальною площею 4,318 млн га в межах України (фактична площа 3,985 млн га) та 402500,0 га в межах акваторії Чорного моря [8].

Відношення фактичної площі природно-заповідного фонду до площі держави («показник заповідності») становить 6,6 \% (рис. 1) [9]. За останні 5 років кількість об’єктів і територій природнозаповідного фонду загальнодержавного та місцевого значення збільшилася на 61 одиницю загальною площею 235238,2094 га (фактично на 182220 га), в тому числі й на території Житомирської області на 1 одиницю (табл. 1), рішенням чотирнадцятої сесії Житомирської обласної ради сьомого скликання «Про утворення лісового заказника місцевого значення "Урочище Дуби"» від 21.12.2017 № 919 - лісовий заказник місцевого значення «Урочище Дуби» [9]. 


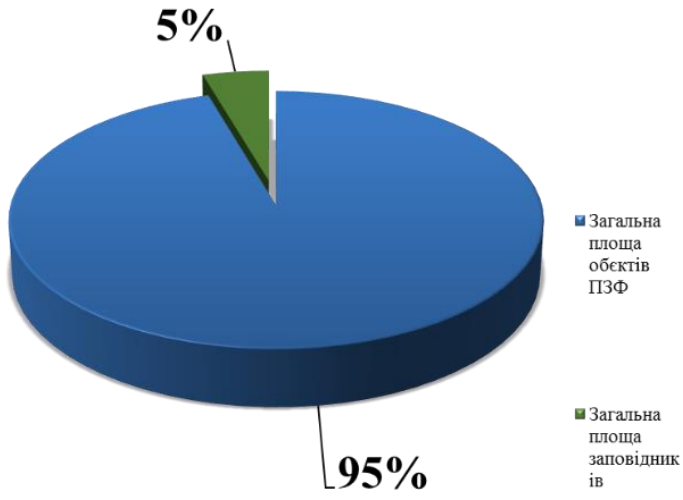

$a$

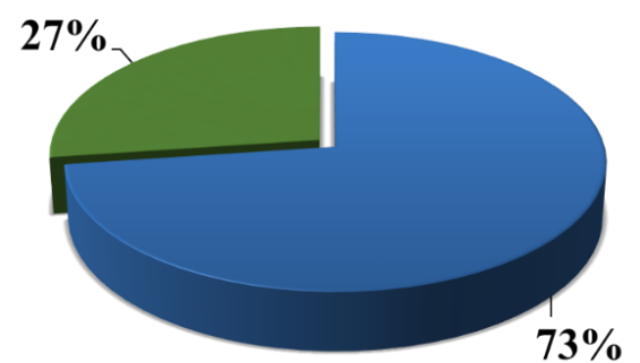

$\sigma$

Рис. 1. Співвідношення загальних площ ПЗФ до площз природних заповідників. а - Украӥна; б - Житомирська область

Таблиияя 1

Динаміка структури природно-заповідного фонду України

\begin{tabular}{|l|c|c|c|c|}
\hline \multirow{2}{*}{$\begin{array}{c}\text { Категорія територій } \\
\text { та об'єктів ПЗФ }\end{array}$} & На 01.01.2007 & На 01.01.2013 & На 01.01.2016 & На 01.01.2021 \\
\cline { 2 - 5 } & площа, тис. га & площа, тис. га & площа, тис. га & площа, тис. га \\
\hline Природні заповідники & 164,3 & 205,3 & 205,3 & 205,3 \\
\hline Біосферні заповідники & 226,3 & 252,1 & 252,1 & 252,1 \\
\hline Національні природні парки & 718,7 & 1215,8 & 1311,6 & 1311,6 \\
\hline Інші категорії & 1854,7 & 1980,7 & 2313,7 & 2369 \\
\hline РАЗОМ & & & & 4318 \\
\hline Фактична площа ПЗФ & 2854,6 & 3922,6 & 4082,8 & \\
\hline
\end{tabular}

Заповідники є в кожному великому природному комплексі [10, 11]:

У зоні мішаних лісів - Поліський та Древлянський заповідники на півночі Житомирської області. Охороняється ландшафт мішаних лісів [11].

У Лісостепі - Канівський (Черкаська область), Медобори (Тернопільська область), Розточчя (Львівська область), Подільські Товтри (Хмельницька область). Охороняються ландшафти лісостепової зони [11].

У Степу - Асканія-Нова i Чорноморський (Херсонська область), Дніпровсько-Орільський (Дніпропетровська область), Луганський (враховує відділи: Стрільцівський Степ, Провальський Степ, Станично-Луганський відділ - усі в Луганській області), Український степовий (Михайлівська цілина в Сумській області, Хомутівський степ у Донецькій області, Кам'яні могили в Запорізькій області), Єланецький степ (Миколаївська область), Дунайські Плавні (Одеська область). Об'єктами охорони є степові ландшафти [11].

У Карпатах - Карпатський, Горгани, Вижнецький, Синевир. Зберігають рідкісні, майже не ушкоджені гірські екосистеми лісового, субальпійського та альпійського поясів [11].

Згідно з облікованими даними Управління екології та природних ресурсів Житомирської обласної державної адміністрації станом на 01.01.2021 року природно-заповідний фонд області складається із 222 територій та об’єктів загальною площею 136 749,9648 га, повний перелік територій та об'єктів природнозаповідного фонду загальнодержавного та місцевого значення розташованих у Житомирській області вказано в [12].

На території Житомирської області знаходяться два природні заповідники: Поліський природний заповідник та природний заповідник «Древлянський», загальна площа яких становить 50976,84 га, а саме: Древлянського заповідника - 30872,84 га та Поліського заповідника - 20104 га. В області зареєстровано 2 пам'ятки природи загальнодержавного та 34 місцевого значення, що мають особливе природоохоронне, наукове, естетичне і пізнавальне значення. 3 метою збереження їх у природному стані переважна більшість їх облаштована огорожею, а гідрологічні об'єкти, як правило, використовуються для відпочинку 
мешканців. У межах пам'яток природи забороняється діяльність, яка загрожує їх збереженню або призводить до їх деградації [1, 12]. На території області створено заказники загальнодержавного та місцевого значення, в яких обмежено деякі види господарської діяльності людини, постійно або в певні періоди охороняються усі чи окремі види тварин, рослин, частини природного комплексу [12]

Окрім заповідників, заказників та пам'яток природи, в області є парки [12] - пам'ятки садовопаркового мистецтва, в яких втілено кропітку працю попередніх поколінь та досвід архітекторів і садівників минулих століть, в тому числі 5 загальнодержавного і 20 місцевого значення загальною площею - 348,8748 га. Три дендропарки займають площу 14,9 га. Це, зокрема, Шодуарівський парк, заснований у XIX столітті відомим меценатом дослідником Волині I.М. Шодуаром, разом зі свою філією Гідропарком - він займає територію площею 91 га [12]. Верхівнянський парк у Ружинському районі, Івницький парк в Андрушівському районі, Новочорторійський парк села Нова Чортория Любарського району, Трощанський парк у Чуднівському районі та Городницький парк у Новоград-Волинському районі, Ботанічний сад Поліського національного університету м. Житомира, дендрологічний парк «Гладковицький» Овруцького району та інші. Фінансуються ці об'єкти переважно за рахунок туристського відвідування, що надає змогу вживати заходи щодо запобігання самосіву, збереження деревних, чагарникових і квіткових рослин, здійснювати догляд за насадженнями. [13] Але це не забезпечує оптимального догляду за екосистемами природоохоронних об'єктів Житомирщини, тому найважливішою умовою є забезпечення високого рівня екологічної освіти та культури поводження в парках відпочинку населення [14]. Актуальною залишається наукова проблема практичної реалізації забезпечення екологічної безпеки на теренах туристичних дестинацій. Кількісна оцінка джерел та наслідків екологічного впливу на довкілля туристичних дестинацій в Україні не проводиться, це викликає негативні наслідки: зокрема відсутність збалансованих методів управління відходами спричиняє їх накопичення та збільшення обсягів, що, в свою чергу негативно впливає на стан екосистем [15].

Варто зазначити, що 3 роками відбувається поступове збільшення кількості територій природоохоронного значення, поява нових об'єктів, які привертають увагу науковців, як польових лабораторій для фундаментальних та прикладних наукових досліджень. Саме на заповідних територіях доцільно проводити науковий моніторинг природних процесів 3 метою визначення закономірностей функціонування екосистем [10].

Аналіз опрацьованої літератури свідчить про те, що природоохоронні території заповідників Житомирської області досліджені недостатньо [16]. Одержані результати мають фрагментарний характер, що не дозволяє забезпечити системний підхід до вивчення особливостей організації та існування природних екосистем. Тому актуальним $є$ подальше вивчення особливостей формування, існування i функціонування екосистем, їх структури, аналізу впливу біотичних та абіотичних чинників, удосконалення методів наукового моніторингу природних процесів для встановлення закономірностей функціонування територій природоохоронного значення [10].

Мета роботи - вивчення репрезентативності природних екосистем у природно-заповідному фонді Житомирської області, їх стану та перспектив розвитку.

Об'єкт досліджень - наземні та прісноводні екосистеми Житомирського Полісся, зокрема, лісові, річкові та болотні природні екосистеми.

Методика досліджень. Весь цикл досліджень репрезентативності природних екосистем можна умовно поділити на чотири етапи: попередній, початковий, основний і додатковий [17].

Попередній етап складався із вибору об'єктів для досліджень, що враховує знайомство з фондовими, картографічними і таксаційними матеріалами, маршрутне обстеження територій природно-заповідного фонду [17].

Визначено коло найбільш придатних для досліджень об'єктів, це, передусім, площі заказників, резерватів, інших заповідних територій. На цьому етапі досліджень також зібрано відомості про природні умови регіону, з метою вивчення різних типів природних екосистем. Як об'єкт досліджень було обрано природні заповідники області. Адже державні заповідники - це основна і найбільш поширена на наших теренах категорія абсолютно заповідних територій, що не має аналогів у зарубіжних країнах. Термін «заповідник» походить від слова «заповідь», і таким чином вже саме це поняття означає повну заборону втручання людини в природні екосистеми.

Початковий етап передбачає насамперед проведення комплексу робіт 3 відбору матеріалів для дослідження: карти, схеми, фотоматеріали, наукові дослідження, опрацювання проєктів організації території та охорони природних комплексів, аналізування літописів природи, що ведуть у науковому підрозділі заповідників та їх картування.

Основний етап передбачає безпосередньо проведення самих досліджень за наявною методикою, а саме проведення польових обстежень територій заповідників, збір необхідних даних, аналіз отриманих даних, їх зіставлення. Проведено обробку отриманих результатів за допомогою математичних розрахунків, статистичних показників і зведення цих результатів до загального висновку проведених досліджень. 
Польові обстеження територій заповідників, що розташовані в Овруцькому, Олевському та Народицькому районах Житомирської області, проведені восени 2021 року.

Статистичні дані отримані в Управлінні екології та природних ресурсів Житомирської обласної державної адміністрації.

Додатковий етап передбачає складання таблиць, графіків, номограм для більш кращого наочного зображення отриманих результатів.

Після обрахунку параметрів, отриманих під час проведення польових обстежень та аналізу зібраної статистичної інформації за загальними методиками, що використовуються у лісовому та водному господарствах, подальша обробка даних проводилася за допомогою програми Microsoft Excel.

Результати досліджень. Під час проведення досліджень здійснювалося вивчення представленості природних екосистем у природному заповіднику «Древлянський» та Поліському природному заповіднику.

Територія, на якій створено природний заповідник «Древлянський» [18], знаходиться у Народицькому районі Житомирської області на південь та південний-схід від райцентру смт. Народичі. Площа заповідання становить 30872,84 га (рис. 2).

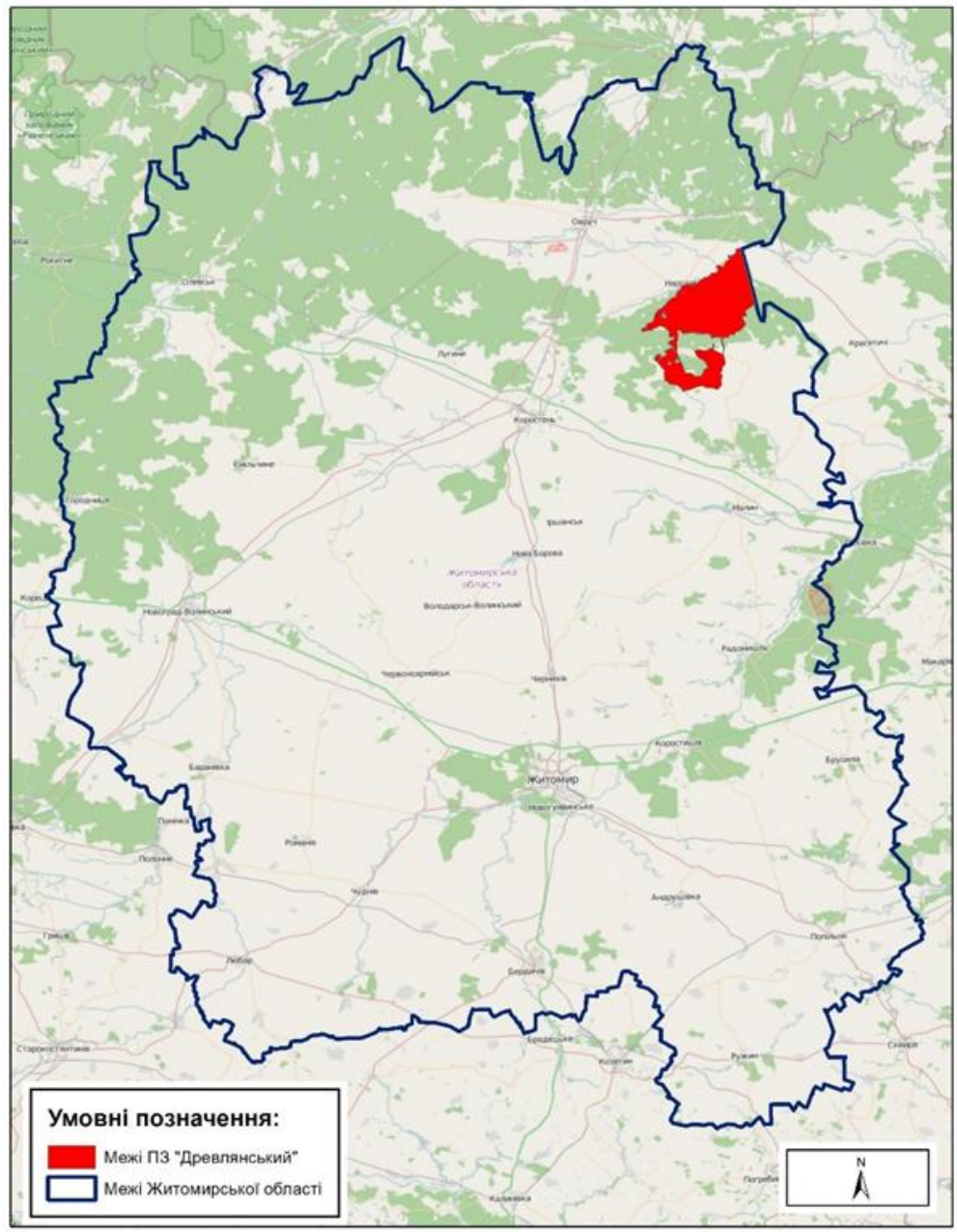

Рис. 2. Територія розміщення природного заповідника «Древлянський»

Нині головна частка цієї території становить собою ліси, які знаходяться у віданні ДП «Народицький спецлісгосп» (всього 16823 га), які входять до складу трьох лісництв: Народицького (8294 га), Кліщівського (5034 га) та Заліського (3495 га). Значно менша площа лісів належить Радчанському лісництву ДП «Народицький лісгосп АПК» $(57,7$ га) $[18,19]$. Решта площі заповідника є землями запасу Народицької районної ради (2430 га), Народицької селищної ради (10470,74 га), Мотійківської (673,3 га) та Селецької (418,1 га) сільських рад. До складу Заповідника відійшла більша частина території ландшафтного заказника місцевого значення «Древлянський», створеного згідно з рішенням 8-ї сесії Житомирської обласної ради № 191 від 05.01.2007 р. на загальній площі 40055,6 га [18].

Клімат території заповідника помірно-континентальний, формується при взаємодії вологих і теплих зимою та прохолодних літом атлантичних повітряних мас західного переносу, а також сухих холодних взимку і жарких влітку континентальних повітряних мас Азії [20]. 
За сучасним геоботанічним районуванням [21], територія заповідника належить до Європейської широколистянолісової зони, Східноєвропейської (Сарматської) провінції, Центральнополіського округу грабово-дубових, дубових, дубово-соснових лісів, заплавних лук та евтрофних боліт і Київського правобережного округу грабово-дубових, дубово-соснових лісів, заплавних лук та евтрофних боліт.

Загальна характеристика рослинності заповідника наводиться за даними О.О. Орлова [13]. Розподіл площі заповідника за типами рослинності є таким: ліси - 54,68 \%; луки - 34,58 \%; болота - 0,12 \%. Значну частку території заповідника займають антропогенні біотопи: землі населених пунктів - 2,75 \% та перелоги $-7,87 \%$ [20].

3 наведеного розподілу можна зробити висновок, що у межах заповідника переважає лісова рослинність. Також слід підкреслити, що лісистість території з часом 3 54,68 \% збільшиться приблизно до $63 \%$, переважно за рахунок штучного та природного заліснення площ перелогів та переводу молодих лісових насаджень на них у вкриту лісом площу.

Ліси збереглися переважно у межиріччях Уж-Жерев та Уж-Звіздаль. Переважають у заповіднику соснові ліси на флювіогляціальних та моренних відкладах, значні площі також займають дубово-соснові ліси, що обумовлюється багатством грунтів, які сформувалися на досить потужних моренних відкладах. На лесових островах вони приурочені до верхніх частин рельєфу і представлені сосново-дубовими лісами ліщиново-орляковими. Значні площі тут займають похідні ліси штучного походження - середньовікові та молоді чисті соснові ліси на місці сосново-дубових, які, проте, зберегли багатство трав'яночагарничкового ярусу в їх деревостані [18].

Базове лісовпорядкування на території лісових підприємств виконано у різні роки, а саме: у Народицькому спецлісгоспі в 2008 році, у Народицькому лісгоспі АПК в 2011 році. За даними землевпорядних органів ці землі представлені радіоактивно забрудненими ділянками виселених населених пунктів та ділянками, які до аварії на ЧАЕС використовувалися в основному як сіножаті або пасовища. За час, що пройшов після аварії на ЧАЕС, значна частина земель запасу вже заросла лісовою рослинністю.

Для отримання більш точної характеристики всіх лісових ділянок та більш повного і точного набору видів та обсягів потрібних для виконання на них тих чи інших лісівничих заходів потрібно у найближчі роки провести на всій території заповідника весь комплекс лісовпорядних робіт [22].

У зв'язку зі створенням заповідника відповідно до постанови Кабінету Міністрів України від 16.05.2007 № 733 «Про затвердження поділу лісів на категорії та виділення особливо захисних лісових ділянок» проєктується зарахування всіх його лісових ділянок до категорії ліси природоохоронного, наукового, історико-культурного призначення, а саме до природних заповідників [22].

Встановлені класи стиглості насаджень заповідника відповідно до чинних «Оптимальных возрастов рубок в лесах Украинской ССР», затверджених Міністерством лісового господарства України 21 жовтня 1983 року [22].

Таблиия 2

Розподіл лісових ділянок за їх категоріями

\begin{tabular}{|l|c|c|}
\hline \multicolumn{1}{|c|}{ Категорія лісових земель } & га & $\%$ \\
\hline Вкриті лісовою рослинністю лісові ділянки - усього & 15096,6 & 94,67 \\
\hline у т. ч. лісові культури & 7681,6 & 48,17 \\
\hline Не вкриті лісовою рослинністю лісові ділянки - усього & 850,9 & 5,33 \\
\hline у тому числі: & & \\
\hline - незімкнуті лісові культури & 145,5 & 0,91 \\
\hline - зруби & 13,2 & 0,08 \\
\hline - галявини, пустирі & 328,2 & 2,06 \\
\hline - біогалявин & 27,0 & 0,17 \\
\hline - лісові шляхи, просіки тощо & 337,0 & 2,11 \\
\hline Разом лісових ділянок & 15947,5 & 100,00 \\
\hline
\end{tabular}

Практично насадження всіх панівних порід заповідника $є$ характерними для Полісся України. Насадження з пануванням порід-інтродуцентів займають тільки 0,09 \% площі лісових ділянок.

У заповіднику переважають насадження 1 та 2 класів бонітету $(82,71 \%)$. Середній клас бонітету насаджень становить 1,7 при середньому їх віці 58 років та середній повноті 0,79 .

У заповіднику помітно переважають середньовікові насадження (68,46 \% за площею та 85,20\% за запасом). Стиглі і перестійні насадження в сумі займають 1,86 \% за площею та 2,10 \% за запасом.

За час після проведення останніх лісовпорядних робіт, тобто з 2008 року, у лісових ділянках, що зараз передані у користування заповіднику, Народицьким спецлісгоспом було виконано рубки головного користування на площі 9,4 га та вибіркові санітарні рубки на площі 3,1 га, а також створено лісові культури на вирубках минулих років на площі 145,5 га (у 2008 році - 573,7 га, у 2009 році - 87,8 га). Ці лісові 
культури на даний час ще знаходяться у категорії незімкнутих. Окрім того, у 2004 році були створені лісові культури на площі 45,0 га та у 2006 році на площі 6,4 га. Вони вже переведені у категорію ділянок, вкритих лісовою рослинністю. Всі наведені вище обсяги робіт виконувалися на ділянках із радіаційним

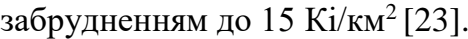

За час після аварії на ЧАЕС природним шляхом вкрилися лісовою рослинністю 2552,0 га земель, в тому числі $з$ панівними породами: сосна звичайна - 2227,4 га, береза повисла - 206,9 га, вільха чорна 117,7 га. Ці землі раніше в основному були представлені різними угіддями сільськогосподарського призначення.

Взагалі на теперішній території заповідника виявлено 7681,6 га насаджень штучного походження (лісових культур), що становить 50,88 \% від загальної площі земель, вкритих лісовою рослинністю. Найстарші лісові культури сосни звичайної віком 118 років виявлені на площі 6,6 га. Станом на 01.01.2018 року на території заповідника обліковувалося 145,5 га незімкнутих лісових культур віком від 4 до 5 років. 3 них культури сосни звичайної - 20,2 га, берези повислої - 125,3 га.

За даними лісовпорядкування всі лісові культури (в тому числі і незімкнуті), що створені за останні 10 років, знаходяться у задовільному стані.

Поліський природний заповідник має колосальне наукове значення як місце збереження природних екосистем Українського Полісся, поліської флори і фауни та їх зникаючих видів. Його роль у справі охорони і вивчення унікальних природних комплексів Полісся важко переоцінити. Крім того, Поліський заповідник $є$ унікальною базою для проведення наукових радіологічних досліджень [24].

Поліський природний заповідник займає територію площею 20,104 тис. га [25], до його складу входить три лісництва: Копищанське - 6,910 тис. га; Пержанське - 5,694 тис. га; Селезівське - 7,497 тис. га (рис. 3).

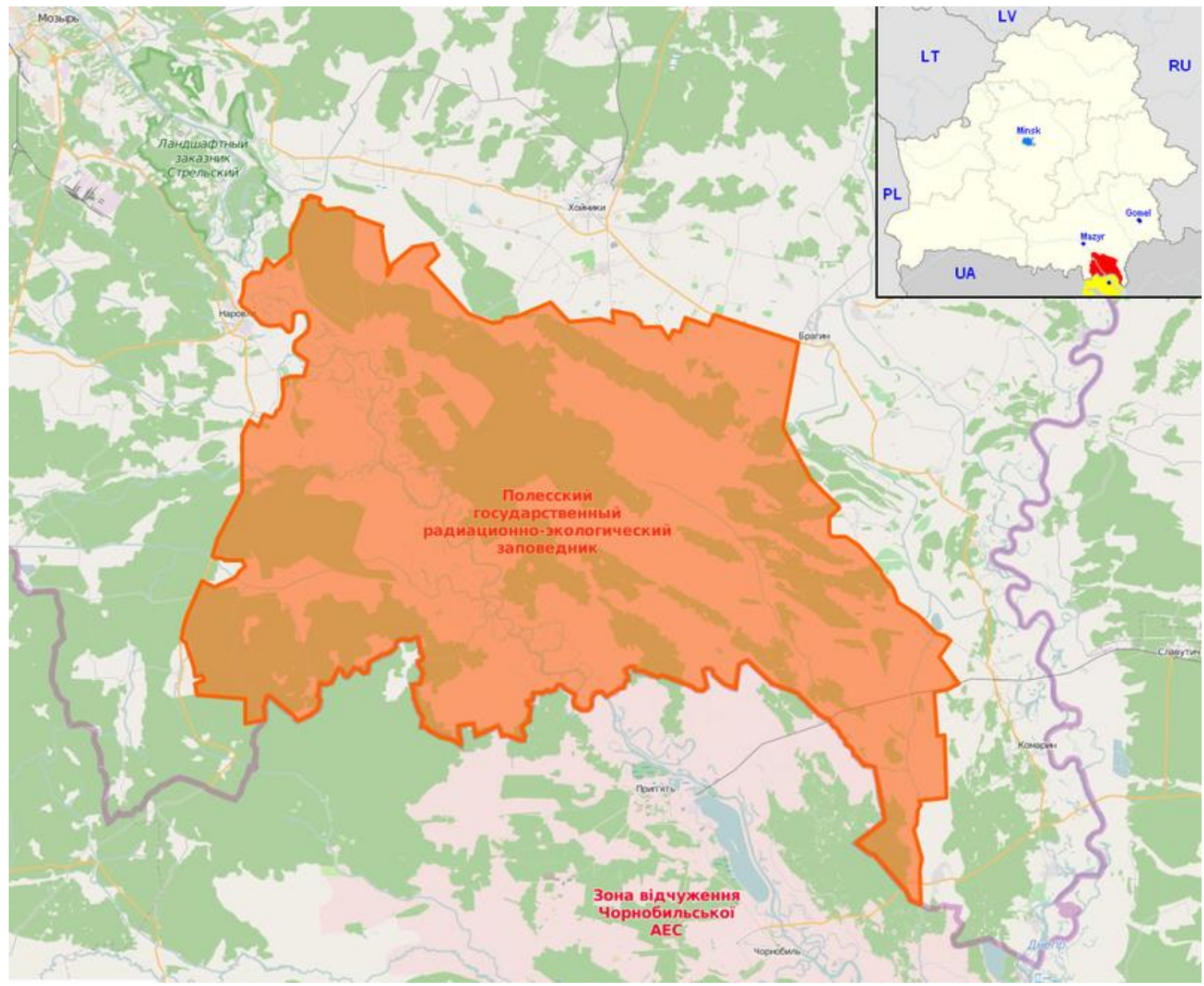

Рис. 3. Територія розміщення Поліського природного заповідника

3 метою захисту природних комплексів від впливу господарської діяльності на прилеглих до заповідника територіях ДП «Словечанське ЛГ» і ДП «Білокоровицьке ЛГ», СТОВ «Хочинське» і СТОВ «Перемога», ПСП «Бігунь» відповідно до постанови Ради Міністрів УРСР від 29.11.1972 року № 544 та рішення III сесії 23 скликання Житомирської обласної ради народних депутатів від 17.09.1998 року встановлена охоронна зона загальною площею 9878 га. 
Клімат району розміщення заповідника помірно-континетальний з теплим, помірно-вологим літом і м’якою хмарною зимою, з переважанням західних та північно-західних вітрів.

Згідно 3 лісорослинним районуванням територія заповідника належить до зони мішаних лісів Українського Полісся. Середній бонітет деревостанів становить 2,7 м².

Лісовий фонд характеризується такими основними показниками:

- вкрита лісом площа - 17282 га, у т. ч. лісові культури - 5301 га;

- за віковим складом: молодняки - 5240 га, середньовікові насадження - 10975 га, пристигаючі - 917 га, стиглі і перестиглі - 158 га;

- за породним складом: хвойні - 15015,7 га, твердолистяні - 0,2 га, м'яколистяні - 2393 га.

Флора та рослинність заповідника сьогодні досить добре вивчена. Переважну частину лісів становлять молоді сосняки та середньовікові насадження; достигаючі і стиглі дерева займають незначні площі. На території заповідника та його охоронної зони знайдено місця зростання третинних реліктів - найдавніших представників флори Полісся: водяного горіха плавучого, рододендрона жовтого, шейцерії болотної, шолудивника королівського, лікоподієли заплавної, верб чорної та лапландської. Значна частина цих рослин потребує охорони та внесена до Червоної Книги України.

Динамічні тенденції в розвитку рослинності заповідника вивчаються на стаціонарних пробних площах, трансектах, а результати досліджень зазначені в Літописах природи.

У рослинному покриві заповідника переважають соснові ліси, що займають 77,1 \%. На ліси із берези повислої приходиться 16,8 \%, вільхи чорної - 6,1%. Зустрічаються невеликі ділянки осикових та сосноводубових асоціацій. За геоботанічною класифікацією найбільш поширені лишайникові, зеленомошнолишайникові й зеленомошні бори. Характерна значна заболоченість і переважання рідколісних оліготрофних боліт та відкритих мезотрофних.

У заповіднику постійно проводяться моніторингові дослідження найважливіших об' єктів природи цього краю. Зокрема в заповіднику діє мережа гідрологічних постів. Науковий відділ заповідника веде неперервний моніторинг раритетної рослинності Центрального Полісся. Заповідник є базою для наукових досліджень у галузі лісівництва (вивчення продуктивності, штучного і природного поповнення лісів, закладання дослідів 3 вирощування швидкорослих порід та інтродукції нових рослин), геоботаніки та болотознавства. Попереднім лісовпорядкуванням у заповіднику було виявлено 79 га не вкритих лісовою рослинністю земель, в тому числі згарищ та загиблих насаджень - 55 га, зрубів - 9 га, галявин - 15 га (табл. 3).

Таблиця 3

Розподіл загальної площчі природного заповідника за категоріями земель, га

\begin{tabular}{|l|c|c|}
\hline \multicolumn{1}{|c|}{ Категорія земель } & га & $\%$ \\
\hline Вкриті лісовою рослинністю лісові ділянки -усього & 17284,32 & 89,3 \\
\hline у тому числі лісові культури & 5301 & 48,17 \\
\hline Не вкриті лісовою рослинністю лісові ділянки - усього & 215 & 5,33 \\
\hline у тому числі: & 102 & 0,91 \\
\hline - незімкнуті лісові культури & 26 & 0,08 \\
\hline - зруби & 57 & 2,06 \\
\hline - галявини, пустирі & 132 & 0,17 \\
\hline - згарища, загиблі насадження & 360 & 2,11 \\
\hline - лісові шляхи, просіки тощо & 10,7 \\
\hline Нелісові землі-усього & 2143 & 9,7 \\
\hline Сільськогосподарські угіддя & 2143 & 0,3 \\
\hline у тому числі: & & 0,7 \\
\hline - рілля & 7 & 1,1 \\
\hline - сіножаті & 125 & 21,7 \\
\hline - води & 24 & 0,5 \\
\hline - болота & 1966 & 0,5 \\
\hline - садиби & 10 & 0,1 \\
\hline - пасіки & 10 & 100 \\
\hline - траси & 1 & \\
\hline Разом & 20104 & \\
\hline
\end{tabular}

3 проаналізованих даних, отриманих в результаті зіставлення природних екосистем заповідників Житомирщини, можна зробити висновок, що в заповідному фонді України найбільше представлена екосистема лісу (табл. 4), яка $є$ найпоширенішою природною екосистемою Житомирського Полісся зокрема і є типовою для всього Українського Полісся - зони мішаних лісів та характерною для всієї України. 
Разом $з$ тим, необхідно зазначити, що за площею заповідання Поліський природний заповідник переважає над Древлянським, адже із загальної площі 20104 га землі, вкриті лісом, становлять площу 17282 га, це близько $75 \%$ (рис. 4).

Структура природних екосистем заповідників Житомирської області

\begin{tabular}{|c|c|c|c|}
\hline \multicolumn{2}{|c|}{ ПЗ «Древлянський» } & \multicolumn{2}{|c|}{ Поліський ПЗ } \\
\hline Тип екосистеми & $\begin{array}{l}\text { \% від площі } \\
\text { заповідника }\end{array}$ & Тип екосистеми & $\begin{array}{l}\text { \% від площі } \\
\text { заповідника }\end{array}$ \\
\hline Лic & 54,68 & Лic & 75 \\
\hline Водойми (річки, озера) & 4 & Водойми (річки, озера) & 3 \\
\hline Болото & 0,12 & Болото & 21,7 \\
\hline Луки & 34,58 & Луки & 3 \\
\hline
\end{tabular}

Що ж стосується природного заповідника «Древлянський», то загальна територія відповідно до офіційних даних 30 872,84 га, з них вкритих лісом - 15 947,5 га, що відповідно становить 54,68 \%, за своїм складом це переважно ліси з хвойних порід дерев (рис. 5), зокрема сосни звичайної середньовікової групи (рис. 6).

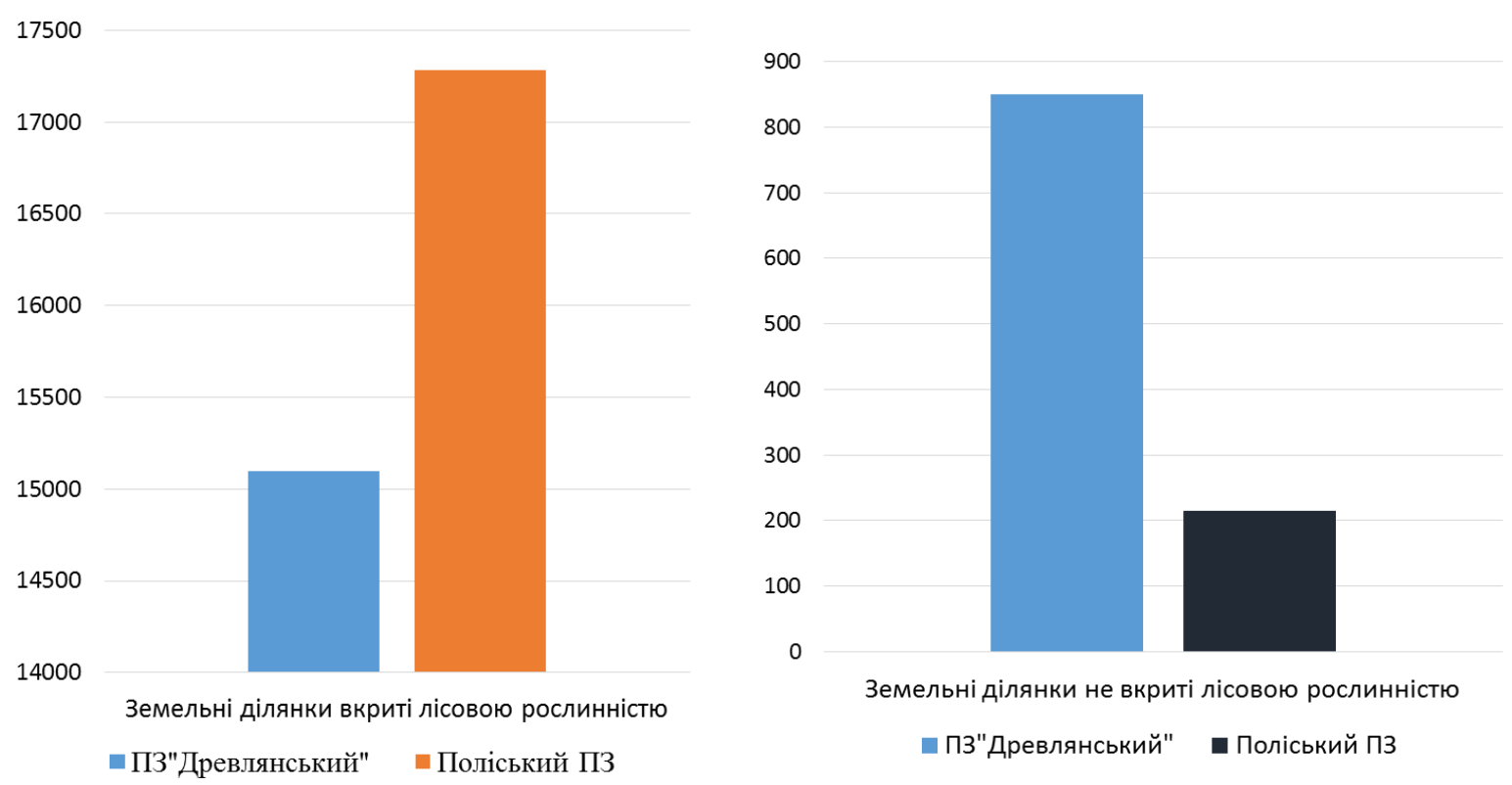

Рис. 4. Розподіл лісових ділянок, га

Екосистема річок [26] на території ПЗ «Древлянський» більш розгалужена ніж на території Поліського заповідника: в його межах протікає аж 7 річок (табл. 5): Уж, Кам’янка, Лозниця, Жерев, Ослів, Звіздаль та Буча, загальною протяжністю на території заповідника 103 км (площею близько 50 га), а на території Поліського природного заповідника знаходиться 4 річки (табл. 6), а саме: Уборть, Болотниця, Жолобниця, Плотниця, загальною протяжністю на території заповідника 48 км, відповідно площею близько 24 га.

Таблиия 5

Основні річки Древлянського заповідника

\begin{tabular}{|c|c|c|c|}
\hline Річка & Місце впадіння & Загальна довжина, км & $\begin{array}{c}\text { Довжина в межах } \\
\text { заповідника, км }\end{array}$ \\
\hline Уж & Прип'ять & 256 & 40 \\
\hline Кам’янка & Уж & 43 & 13 \\
\hline Лозниця & Уж & 14 & - \\
\hline Жерев & Уж & 96 & 15 \\
\hline Ослів & Уж & 15 & 15 \\
\hline Звіздаль & Уж & 32 & 16 \\
\hline Буча & Звіздаль & 25 & \\
\hline
\end{tabular}


Екосистема боліт (рис. 7) у заповідниках помітно відрізняється за кількісними ознаками, так болота у ПЗ «Древлянський» становлять лише 0,12 \% від загальної території заповідника, а у Поліському природному заповіднику - це 21,7 \% від загальної території, 3 площею близько 5000 га, 3 них більша частина - площею 2145 га - знаходяться під міжнародною охороною. За типом найбільш поширені в Поліському природному заповіднику мезотрофні (перехідні) болота, а у Природному заповіднику «Древлянський» переважно евтрофні (низинні), заплавні болота.

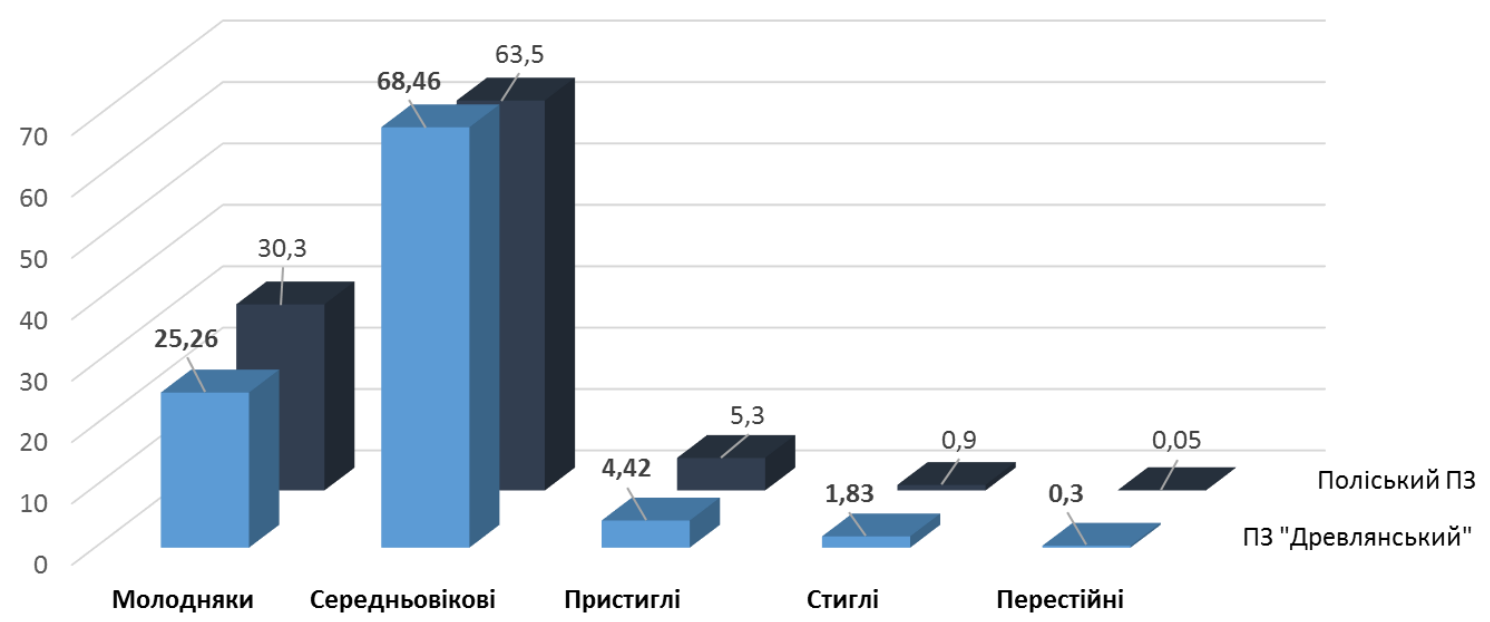

пЗ "Древлянський" Поліський ПЗ

Рис. 5. Розподіл площъі лісових екосистем за віковою структурою, га

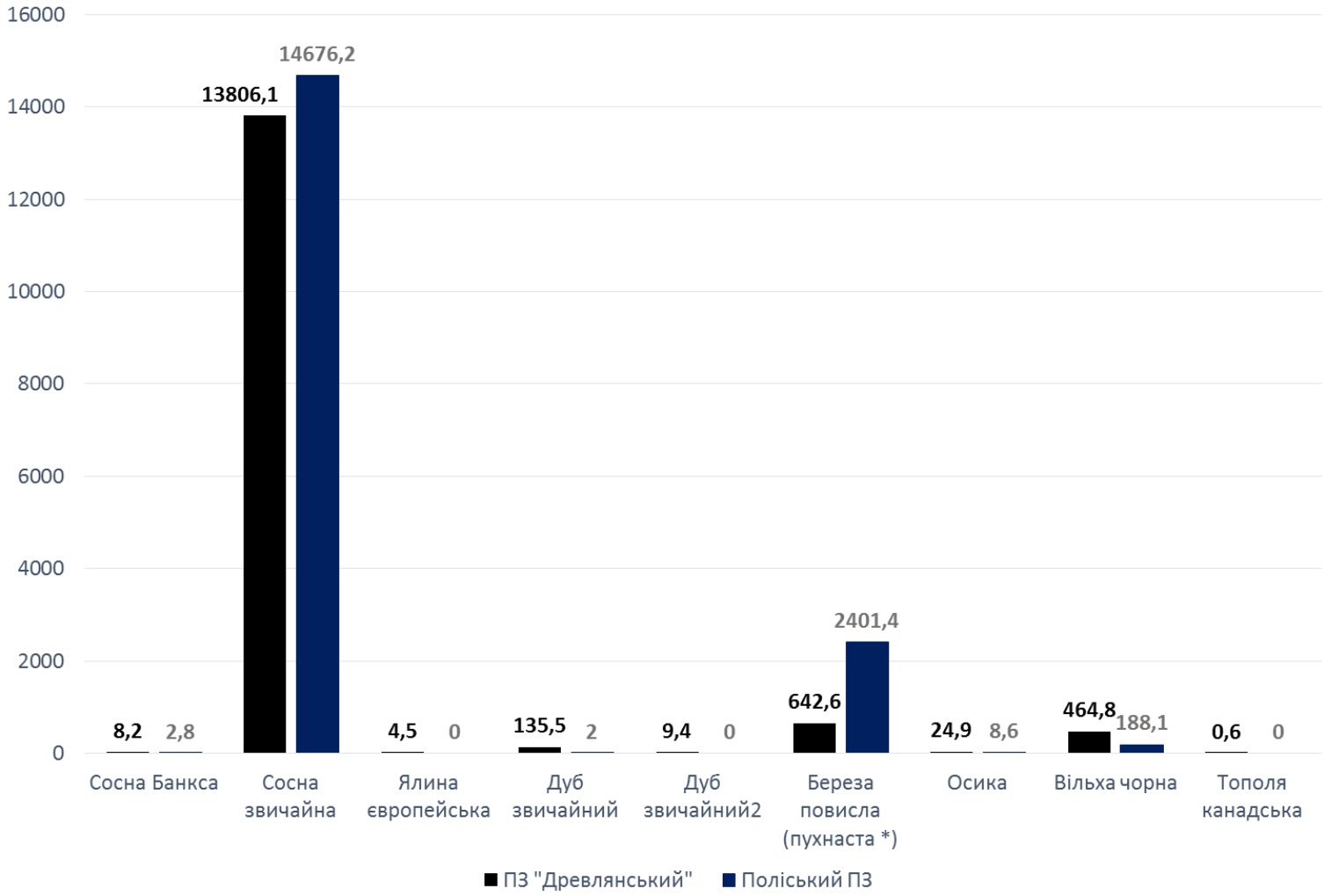

Рис. 6. Розподіл площуі лісових екосистем заповідників за переважаючими породами, га 
Окрім того, в ПЗ «Древлянському» широко представлена екосистема лук, що становить за статистичними даними 34,58 \% від всієї площі заповідника, які мало представлені на території Поліського природного заповідника - це приблизно лише 3 \%. Необхідно додати, що лучні екосистеми динамічні, на характер яких сильно впливають погодні та гідрологічні умови. Що, в свою чергу, можна обгрунтувати наявністю в складі заповідника «Древлянський» земель сільськогосподарського призначення на території Мотійківської, Селецької сільських рад та Народицької районної ради, що зазнали найбільшого радіаційного впливу за наслідками Чорнобильської катастрофи.

Таблиця 6

Основні річки Поліського заповідника

\begin{tabular}{|c|c|c|c|}
\hline Річка & Місце впадіння & Загальна довжина, км & $\begin{array}{c}\text { Довжина в межах } \\
\text { заповідника, км }\end{array}$ \\
\hline Уборть & Прип’ять & 256 & 17 \\
\hline Болотниця & Уборть & 40 & 20 \\
\hline Жолобниця & Болотниця & 24 & 7 \\
\hline Плотниця & Уборть & 20 & 4 \\
\hline
\end{tabular}

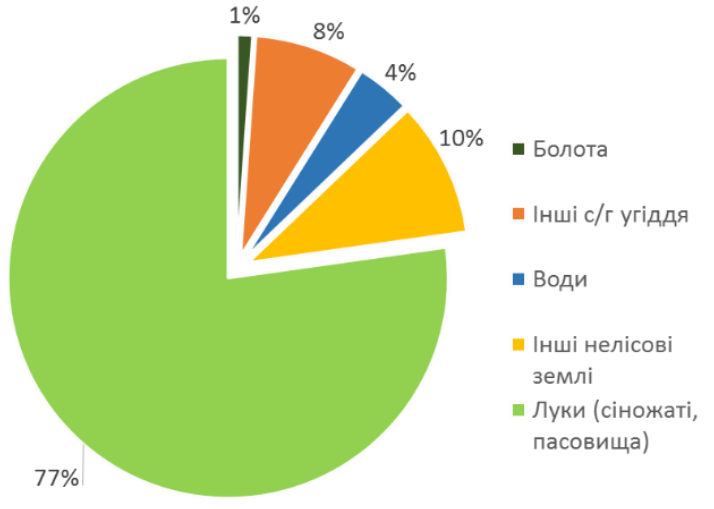

ПЗ «Древлянський»

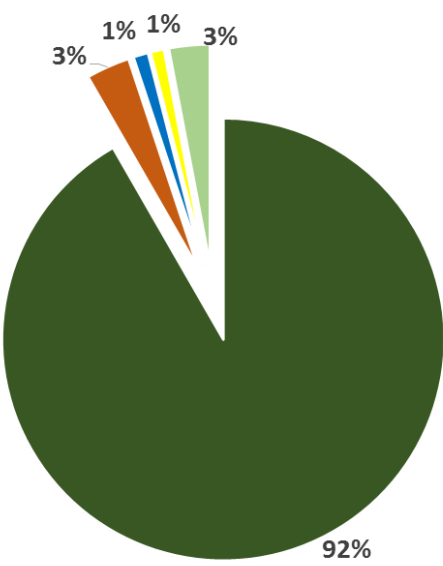

Поліський ПЗ

Рис. 7. Розподіл нелісових екосистем заповідників Житомирської області

Древлянський заповідник є одним із елементів національної екологічної мережі (Народицьке суб'ядро Чорнобильського екологічного ядра), також є важливою IBA-територією - «Долина р. Уж», яка має велике значення для збереження популяцій багатьох видів птахів на національному та загальноконтинентальному рівнях [3].

Висновки та рекомендації. Питання щодо дослідження представленості природних екосистем у природно-заповідному фонді Житомирської області в умовах прогресуючих антропогенно зумовлених змін природних ландшафтів зони мішаних лісів Полісся не втрачає свої актуальності і потребує вирішення 3 метою збереження природного потенціалу навколишнього середовища та його ландшафтів, для визначення особливостей організації та існування природних екосистем, зокрема в заповідниках Житомирщини, та розбудови екологічної мережі.

Найбільш важливі наукові та практичні результати дослідження, висновки і рекомендації:

1. Аналізуючи стан екосистем Центрального Полісся було встановлено, що площа території та об'єктів природно-заповідного фонду області зростає й становить 4,5 \% від всієї території, разом з тим, показник заповідності порівняно з іншими регіонами України низький;

2. Під час досліджень було встановлено, що переважна більшість існуючих в Житомирській області територій та об’єктів ПЗФ головним чином сконцентрована в Олевському та Овруцькому районах;

3. Аналізуючи репрезентативність природних екосистем заповідників Житомирщини було встановлено, що у Природному заповіднику «Древлянський» лісові екосистеми становлять 54,68 \%, лучні - 34,58 \% та водні - 4 \%, однак болота майже не представлені та складають 0,12 \%, а в Поліському природному заповіднику наявна перевага лісових (74 \%) та болотних $(21,9 \%)$ екосистем, а луки становлять лише 3 \% від загальної площі заповідників. При цьому спостерігається зменшення водно-болотних угідь на території обох заповідників; 
4. Польовими обстеженнями територій заповідників встановлено фактичну відсутність заходів щодо оздоровлення лісових екосистем на території заповідників з 2013 року;

5. Одним із кроків для збереження існуючих екосистем Полісся $є$ необхідність проведення територіальних змін щодо охоронних зон навколо заповідників;

6. 3 метою покращення функціонування існуючої екологічної мережі та збереження прісноводних екосистем Центрального Полісся необхідно пришвидшити:

- встановлення меж прибережно-захисних смуг вздовж річок і навколо водойм, які виконують роль екокоридорів на території Житомирської області;

- забезпечення відновлення ключових елементів екосистем, які зазнали руйнацій, та догляд за існуючими природніми екосистема заповідників;

- створення та розширення охоронних зон природних заповідників, їх належна охорона;

- $\quad$ впровадження системного підходу до вивчення особливостей організації та існування природних екосистем;

7. Необхідним заходом є активізація наукових досліджень на базі заповідних територій, буферних i охоронних зон, залучення та посилення ролі наукових установ України у науково-методичному забезпеченні, проведення досліджень та координація роботи природних заповідників Житомирщини 3 метою збереження екосистем;

8. Природоохоронні території заповідників досі є недостатньо дослідженими. Одержані результати мають фрагментарний характер, що не дозволяє забезпечити системний підхід до вивчення особливостей організації та існування природних екосистем. Тому актуальним $\epsilon$ подальше вивчення особливостей формування, існування і функціонування екосистем, їх структури, аналіз впливу біотичних та абіотичних чинників, удосконалення методів наукового моніторингу природних процесів для встановлення закономірностей функціонування територій природоохоронного значення.

\section{Список використаної літератури:}

1. Про природно-заповідний фонд : закон України № 2456-12 від 19.06.1992 [Електронний ресурс]. - Режим доступу : http://zakon.rada.gov.ua/laws/show/995_002.

2. Марков Ф.Ф. Природно-заповідний фонд Житомирської області: проблеми збереження та перспективи розвитку : VI Міжнародна наукова конференція 4-6.10.2011 p. / Ф.Ф. Марков, А.І. Гузій. - Дніпропетровськ : ДНУ, 2011 [Електронний ресурс]. - Режим доступу : https://nadoest.com/v-v-balekovsekij-levivsekijnacionalenij-agrarnij-universitet-stor-3.

3. Осадчук К.О. Природно-заповідний фонд Житомирської області / К.О. Осадчук, І.В. Давидова // Сталий розвиток країни в рамках Європейської інтеграції : тези Всеукраїнської науково-практичної конференції 9 листопада 2017 p. - С. 96-98 [Електронний ресурс]. - Режим доступу : https://conf.ztu.edu.ua/wpcontent/uploads/2017/12/96.pdf.

4. Дані з офіційного сайту Управління екології та природних ресурсів Житомирської обласної державної адміністрації [Електронний ресурс]. - Режим доступу : http://www.ecology.zt.gov.ua/.

5. Природно-заповідний фонд екологічної мережі Поділля в структурі адміністративно-територіального поділу // Українська екологічна асоціація «Зелений світ» Хмельницька обласна організація [Електронний ресурс]. Режим доступу : https://zelenysvit.at.ua/publ/analitika/prirodno_zapovidnij_fond_ekologichnoji_merezhi_podillja _v_strukturi_administrativno_teritorialnogo_podilu/2-1-0-6.

6. Домаранський А.О. Концепція ландшафтного різноманіття як основа оптимізації мережі природнозаповідного фонду (на прикладі Кіровоградської області) : дис. ... к.геогр.н. : 11.00.01 / А.О. Домаранський.Львів : ЛНУ ім. Івана Франка, 2005.

7. Дідух Я.П. Теоретичні підходи до створення класифікації екосистем / Я.П. Дідух // Український ботанічний журнал. - 2005. - № 1. - С. 3-14.

8. Дані з офіційного сайту Міністерства екології та природних ресурсів [Електронний ресурс]. - Режим доступу : https://cutt.ly/3TGUiT5

9. Дані з офіційного сайту Міністерства екології та природних ресурсів [Електронний ресурс]. - Режим доступу : https://mepr.gov.ua/news/37155.html.

10. Дудка $A$. Сучасний стан вивчення екосистем природно-заповідних територій України / A.Дудка, Н.Волошина // Екологія та охорона природи. - НПУ ім. М. Драгоманова. - 2016. - № 6. - С. 117-123.

11. Заповідники України [Електронний ресурс]. - Режим доступу : https://zapovidnukuukr.ucoz.ua/.

12. Природно-заповідний фонд Житомирської області [Електронний ресурс]. - Режим доступу : https://ecology.zt.gov.ua/Biorecursy.html

13. Екологічна стежка (методика, організація, характеристика модельної стежки «Лісники») / за ред. д.б.н., проф. Я.П. Дідуха. - К. : Фітосоціоцентр, 2008. - 88 с.

14. Концептуальні засади еколого-освітньої діяльності в природно-заповідних установах України / М.П. Стеценко, Г.В. Парчук, О.3. Петрович та ін. - К., 2005. - 16 с.

15. Assessment of the Condition of Pine Plantations in the Area of Influence of Municipal Waste Landfills on the Example of the Zhytomyr Landfill, Ukraine / M.Korbut, M.Malovanyy, I.Davydova et al. // Ecological Engineering \& Environmental Technology, 2021. - № 22 (5). - P. 40-46.

16. Заповідна Житомирщина / О.О. Орлов, С.П. Сіренький, А.В. Подобайло, В.А. Санін. - Київ : Фітосоціоцентр, 2001 - 196 с 
17. Етапи роботи над навчальним проектом [Електронний ресурс]. - Режим доступу : https://school.hometask.com/etapi-roboti-nad-navchalnim-proektom/.

18. Малиновський А.С. Древлянський природний заповідник, його місце в мережі природно-заповідного фонду України та актуальні завдання наукових досліджень на його території / А.С. Малиновський, О.О. Орлов, I.Г. Грабар // Вісник ЖНАЕУ. - 2010. - № 1. - С. 19-36 [Електронний ресурс]. - Режим доступу : http://ir.znau.edu.ua/bitstream/123456789/578/1/Drevlyansky_nature_preserve.pdf.

19. Державний лісовий кадастр України [Електронний ресурс]. - Режим доступу : http://dklg.kmu.gov.ua/forest/control.

20. Літопис природи Природний заповідник «Древлянський» [Електронний ресурс]. - Режим доступу : https://drevlyansky.in.ua/2015/06/10/litopis-prirodi/.

21. Національний атлас України. - 2008 [Електронний ресурс]. - Режим доступу : http://wdc.org.ua/atlas/.

22. Лісовий кодекс України [Електронний ресурс]. - Режим доступу : https://zakon.rada.gov.ua/laws/show/3852-12\#Text.

23. Ландін В.П. Ведення лісового господарства в умовах радіоактивного забруднення / В.П. Ландін // 20 років Чорнобильської катастрофи: погляд у майбутнє : Національна доповідь України. - К. : Атіка, 2006. - С. 107-111.

24. Soil sampling when examining forests for radioactive contamination / V.Melnyk, T.Kurbet, Z.Shelest, I.Davydova // Eastern-European Journal of Enterprise Technologies. - 2020. DOI: 10.15587/1729-4061.2020.209873.

25. Проект організації території Поліського природного заповідника та охорони його природних комплексів. Ірпінь, 1998. - 317 с.

26. Дані з офіційного сайту Житомирського обласного управління водних ресурсів [Електронний ресурс]. Режим доступу : http://http://zouvr.gov.ua/.

\section{References:}

1. Pro pryrodno-zapovidnyj fond, zakon Ukrai'ny No. 2456-12 vid 19.06.1992, [Online], available at: http://zakon.rada.gov.ua/laws/show/995_002

2. Markov, F.F. and Guzij, A.I. (2011), «Pryrodno-zapovidnyj fond zhytomyrs'koi' oblasti: problemy zberezhennja ta perspektyvy rozvytku», VI Mizhnarodna naukova konferencija, 4-6.10.2011 r., DNU, Dnipropetrovs'k, [Online], available at: https://nadoest.com/v-v-balekovsekij-levivsekij-nacionalenij-agrarnij-universitet-stor-3

3. Osadchuk, K.O. and Davydova, I.V. (2017), «Pryrodno-zapovidnyj fond Zhytomyrs'koi' oblasti», Stalyj rozvytok krai'ny v ramkah Jevropejs'koi' integracii', tezy Vseukrai'ns'koi' naukovo-praktychnoi' konferencii', 9 lystopada 2017 r., pp. 96-98, [Online], available at: https://conf.ztu.edu.ua/wp-content/uploads/2017/12/96.pdf

4. Dani z oficijnogo sajtu Upravlinnja ekologii' ta pryrodnyh resursiv Zhytomyrs'koi' oblasnoi' derzhavnoi' administracii', [Online], available at: http://www.ecology.zt.gov.ua/

5. Ukrai'ns'ka ekologichna asociacija «Zelenyj svit» Hmel'nyc'ka oblasna organizacija, «Pryrodno-zapovidnyj fond ekologichnoi' merezhi Podillja v strukturi administratyvno-terytorial'nogo podilu», [Online], available at: https://zelenysvit.at.ua/publ/analitika/prirodno_zapovidnij_fond_ekologichnoji_merezhi_podillja_v_strukturi_admi nistrativno_teritorialnogo_podilu/2-1-0-6

6. Domarans'kyj, A.O. (2005), Koncepcija landshaftnogo riznomanittja jak osnova optymizacii' merezhi pryrodnozapovidnogo fondu (na prykladi Kirovograds'koi' oblasti), Ph.D. Thesis of dissertation, 11.00.01, LNU im. Ivana Franka, L'viv.

7. Diduh, Ja.P. (2005), «Teoretychni pidhody do stvorennja klasyfikacii' ekosystem», Ukrai'ns'kyj botanichnyj zhurnal, No. 1, pp. 3-14.

8. Dani z oficijnogo sajtu Ministerstva ekologii' ta pryrodnyh resursiv, [Online], available at: https://cutt.ly/3TGUiT5

9. Dani $\mathrm{z}$ oficijnogo sajtu Ministerstva ekologii' ta pryrodnyh resursiv, [Online], available at: https://mepr.gov.ua/news/37155.html

10. Dudka, A. and Voloshyna, N. (2016), «Suchasnyj stan vyvchennja ekosystem pryrodno-zapovidnyh terytorij Ukrai'ny», Ekologija ta ohorona pryrody, NPU im. M. Dragomanova, No. 6, pp. 117-123.

11. Zapovidnyky Ukrai'ny, [Online], available at: https://zapovidnukuukr.ucoz.ua/

12. Pryrodno-zapovidnyj fond Zhytomyrs'koi' oblasti, [Online], available at: https://ecology.zt.gov.ua/Biorecursy.html

13. Diduha, Ja.P. (ed.), (2008), Ekologichna stezhka (metodyka, organizacija, harakterystyka model'noi' stezhky «Lisnyky»), Fitosociocentr, K., 88 p.

14. Stecenko, M.P., Parchuk, G.V., Petrovych, O.Z. et al. (2005), Konceptual'ni zasady ekologo-osvitn'oi' dijal'nosti v pryrodno-zapovidnyh ustanovah Ukrai'ny, K., $16 \mathrm{p}$.

15. Korbut, M., Malovanyy, M., Davydova, I. et al. (2021), «Assessment of the Condition of Pine Plantations in the Area of Influence of Municipal Waste Landfills on the Example of the Zhytomyr Landfill, Ukraine», Ecological Engineering \& Environmental Technology, No. 22 (5), pp. 40-46.

16. Orlov, O.O., Siren'kyj, S.P., Podobajlo, A.V. and Sanin, V.A. (2001), Zapovidna Zhytomyrshhyna, Fitosociocentr, Kyi'v, $196 \mathrm{p}$.

17. Etapy roboty nad navchal'nym proektom, [Online], available at: https://school.home-task.com/etapi-roboti-nadnavchalnim-proektom/

18. Malynovs'kyj, A.S., Orlov, O.O. and Grabar, I.G. (2010), «Drevljans'kyj pryrodnyj zapovidnyk, jogo misce v merezhi pryrodno-zapovidnogo fondu Ukrai'ny ta aktual'ni zavdannja naukovyh doslidzhen' na jogo terytorii'», Visnyk ZhNAEU, No. 1, pp. 19-36, [Online], available at: http://ir.znau.edu.ua/bitstream/123456789/578/1/Drevlyansky_nature_preserve.pdf

19. Derzhavnyj lisovyj kadastr Ukrai'ny, [Online], available at: http://dklg.kmu.gov.ua/forest/control

20. Litopys pryrody Pryrodnyj zapovidnyk «Drevljans'kyj», [Online], available at: https://drevlyansky.in.ua/2015/06/10/litopis-prirodi/

21. wdc.org.ua (2008), Nacional'nyj atlas Ukrai'ny, [Online], available at: http://wdc.org.ua/atlas/

22. Lisovyj kodeks Ukrai'ny, [Online], available at: https://zakon.rada.gov.ua/laws/show/3852-12\#Text 
23. Landin, V.P. (2006), «Vedennja lisovogo gospodarstva v umovah radioaktyvnogo zabrudnennja», 20 rokiv Chornobyl's'koi' katastrofy: pogljad u majbutnje, Nacional'na dopovid' Ukrai'ny, Atika, K., pp. 107-111.

24. Melnyk, V., Kurbet, T., Shelest, Z. and Davydova, I. (2020), «Soil sampling when examining forests for radioactive contamination», Eastern-European Journal of Enterprise Technologies, doi: 10.15587/1729-4061.2020.209873.

25. Proekt organizacii' terytorii' Polis'kogo pryrodnogo zapovidnyka ta ohorony jogo pryrodnyh kompleksiv (1998), Irpin', $317 \mathrm{p}$.

26. Dani $\mathrm{z}$ oficijnogo sajtu Zhytomyrs'kogo oblasnogo upravlinnja vodnyh resursiv, [Online], available at: http://http://zouvr.gov.ua/

Осадчук Кароліна Олександрівна - студентка гірничо-екологічного факультету Державного університету «Житомирська політехніка».

Наукові інтереси:

- заповідна справа;

- раціональне природокористування

Давидова Ірина Володимирівна - кандидат сільськогосподарських наук, доцент, доцент кафедри екології Державного університету «Житомирська політехніка».

Наукові інтереси:

- лісівництво;

- промислова екологія;

- радіоекологія.

Корбут Марія Броніславівна - кандидат технічних наук, доцент, доцент кафедри екології Державного університету «Житомирська політехніка».

Наукові інтереси:

- поводження з відходами;

- промислова екологія;

- фітоекологія.

Бондарчук Василь Миколайович - старший викладач кафедри фізики та вищої математики Державного університету «Житомирська політехніка».

Наукові інтереси:

- математичні методи в екології;

- математичне моделювання.

Бабяк Віталій Валерійович - аспірант кафедри розробки родовищ корисних копалин ім. проф. М.Т. Бакка Державного університету «Житомирська політехніка».

Наукові інтереси:

- автоматизація технологічних процесів гірничого виробництва;

- автоматизація процесів обробки каменю;

- екологія гірничого виробництва. 